\title{
Scaling the heights of positive psychology: A systematic review of measurement scales
}

\author{
Courtney E. Ackerman · Meg A. Warren · Stewart I. Donaldson
}

\begin{abstract}
The volume of empirical research on positive psychology topics has grown substantially over the past two decades. This review examines how constructs in positive psychology have been operationalized, measured, validated, cited, and applied to build the science. Based on an archive of 972 empirical articles linked to positive psychology, this review found that 762 articles used at least one measurement scale; 312 measures were created or adapted. Findings reveal a wide range of scales being used to measure a variety of constructs, including scales on both life-enhancing and life-depleting constructs. Key characteristics such as journals, constructs, and scale development and validation information are discussed. There are some reliability analyses and validations occurring within the field, but the creation of new measures far outpaces the validation of existing measures. Weaknesses such as multiple operationalizations may be rooted in inadequate discourse and synthesis. We call for further cross-pollination for a more scientifically robust scholarship in positive psychology.
\end{abstract}

Keywords: positive psychology, wellbeing, happiness, measurement, self-report measure, systematic review

\section{Introduction}

Since the inception of positive psychology in 1998 as a formal area of investigation and lens through which to view psychological phenomena, the empirical research on desirable end states and virtuous traits has grown rapidly. The scientific research in positive psychology has drawn increased attention and research each year (Donaldson, Dollwet, \& Rao, 2015), and has become deeply engaged in the study of subjective wellbeing (Diener, 2013), self-determination (Gagné \& Deci, 2014), positive emotions (Tugade, Shiota, \& Kirby, 2014), character strengths (Peterson \& Seligman, 2004), and positive youth development (Ciocanel, Power, Eriksen, \& Gillings, 2017), among others. In a relatively short period of time, positive psychology has expanded to fields beyond psychology and into interdisciplinary areas of research (e.g., education, public health, political science, neuroscience, and management), influencing a broad range of human pursuits (Donaldson, Csikszentmihalyi, \& Nakamura, 2011).

Despite the rapid growth in research and scholarship, the perceptions of positive psychology as unscientific self-help and popular press psychology have persisted over time (Anderson, 2012; Cabanas \& Huertas, 2014; Ruark, 2009; Woodstock, 2005), as a result of which the scientific foundation of positive psychology is often called into question. Therefore, it is useful to review how constructs in positive psychology have been operationalized, measured, validated, cited, and used to build the science. To this end, we review almost two decades of published research associated with positive psychology through the lens of its measurement.

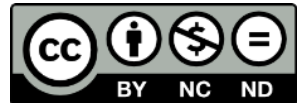

Copyright belongs to the author(s) www.internationaljournalofwellbeing.org 
Through this review, we offer an overview of the sociology of positive psychological science and the history of how positive psychologists have created and used self-report measures.

As positive psychology has inspired empirical research across psychological subdisciplines, there is considerable attention given to the development and measurement of positive constructs and the study of relationships between them in various contexts. Some reviews have synthesized measurement scales used to assess specific constructs (e.g., youth life satisfaction: Proctor, Linley, \& Maltby, 2009; post-traumatic growth: Joseph \& Linley, 2008), in specific areas of application (e.g., psychotherapy: Smock, 2012; dementia research: Stoner, Orrell, \& Spector, 2015), and in specific contexts (e.g., among racial and ethnic groups: Chang, Downey, Hirsch, \& Lin, 2016; in India: Singh, Junnarkar, \& Kaur, 2016). In particular, several reviews focus on wellbeing (e.g., Cooke, Melchert, \& Connor, 2016; Lindert, Bain, Kubzansky \& Stein, 2015; Linton, Dieppe, \& Medina-Lara, 2016; Tsang, Wong, \& Lo, 2012). The current review is intended to push beyond specific topics such as wellbeing and capture a much broader swath of the many constructs associated with positive psychology.

In the current article, we draw from a well-established archive (last update 2014) of English language empirical literature in positive psychology published over 17 years (Donaldson, et al., 2015; Rao \& Donaldson, 2015; Rao, Donaldson, \& Doiron, 2015). Using this archive, we map the generativity in the domains and journals that have published the most used self-report measurement scales, constructs that have been the most measured and cited, development of new scales, validation of existing scales, and operationalizations of popular constructs.

\section{Method}

\subsection{Procedure}

An archive of peer-reviewed articles published between 1998 and 2014 was used to identify measures developed and used in positive psychology since the inception of the field. Since it often takes a few years for measures to become established and used in the literature, we follow up on the most popular scales published in these years with a Google Scholar citation count up to September 2018. This offers an estimate of use and growth in interest in each of the most popular measures.

This archive was developed in 2014 and updated in 2015 to capture articles published from 1998-2014. Previous versions of this archive have been used in past reviews (e.g., Donaldson et al., 2015; Rao \& Donaldson, 2015; Rao et al., 2015); however, the current review involves unique analyses not conducted before. The articles in this archive are English-language peer-reviewed articles collected using the search term "positive psychology" (in quotation marks, with no Boolean operators) in five electronic databases: Academic Search Premier, Business Source Premier, ERIC, PsycINFO, and PsycARTICLES. Thus, the archive consists of 1,628 peerreviewed articles that the authors explicitly linked to positive psychology. Within this archive, the current review screened out non-empirical articles.

This yielded a dataset of 972 empirical articles linked to positive psychology. Of these 972 empirical articles, 762 utilized at least one measurement scale. The 210 articles excluded from the dataset for this review include: 88 articles that utilized interviews, 37 that relied on archival data, 21 that reported observational data, 18 that used simulations in their experiments, 13 that reported the results of focus groups, and five that analyzed biological or physiological data, along with 28 articles that analyzed other types of data. This review was conducted in accordance with PRISMA guidelines for systematic reviews (Moher, Liberati, Tetzlaff, \& Altman, 2009). See Figure 1 below for the PRISMA flowchart for this study. 
Figure 1. PRISMA flow chart outlining the methods used to create the dataset

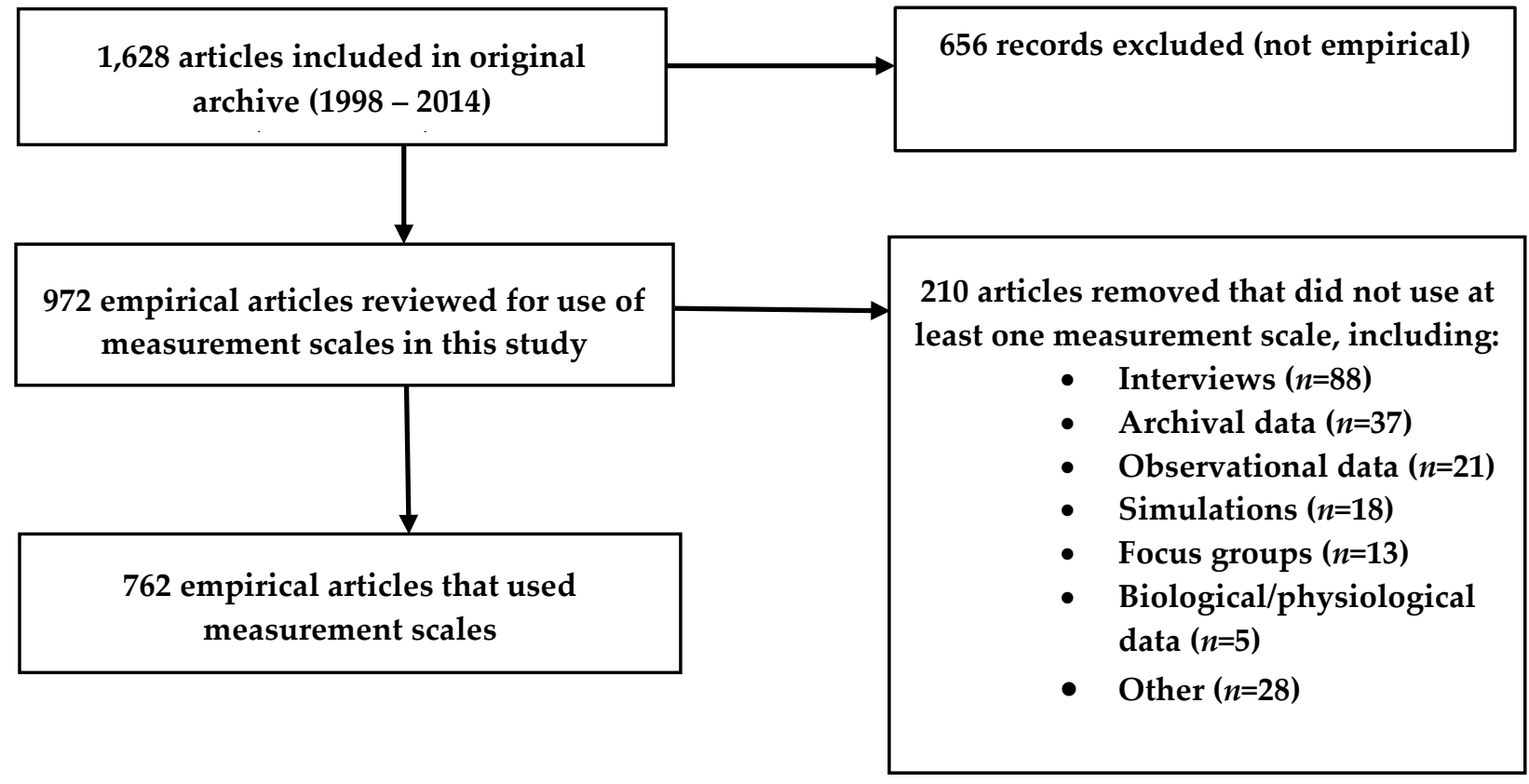

Note: This figure outlines the methods used to narrow down the archive to the final dataset used in this review.

\subsection{Coding}

The original coding for the archive involved an examination of the title, journal, abstract, method, results, and discussion, and articles were coded for: (1) disciplinary domains, (2) journal, (3) data collection methods/study design, and (4) measures used. The inter-rater reliability was calculated as the percentage of coder agreement, which resulted in $90.1 \%$ agreement across all articles and coding categories (for further information, see Donaldson et al., 2015). For this review, additional coding was conducted on the 762 empirical articles that use measurement scales to identify: (5) scale developers, (6) year of development, (7) construct measured, and (8) scale validation information. This additional coding was conducted by the first author, who participated in coding the original archive. As this additional coding focused on objective information and did not involve subjective categorization, the use of multiple coders was not required. One exception was the categorization of a scale as "positive." For this purpose, the first two authors discussed any scales whose categorization was questionable, and such a scale was categorized as positive only after full consensus was achieved.

\subsection{Analysis}

While a range of measures were employed in the dataset, including physiological (e.g., tracking eye movements or heart rate) and observational measurements (e.g., frequency of engagement with others), preliminary analysis revealed a predominant use of self-report (or other-report) measurement scales $-78 \%$ of empirical articles used some type of self-report measurement scale, with $68 \%$ using only self-report measurements. Approximately $13 \%$ of empirical articles relied on focus groups or interviews, $5 \%$ used archival data, $4 \%$ used an observational method, $1 \%$ used biological measures, and the rest used some other type of measure (grades, responses to simulations, writing analysis, etc.). Therefore, we contend that an analysis of measurement scales offers a strong representation of measurement in the field. Consequently, the current review focused on self-report measurement scales. 
Overall, 1,279 established scales were cited in the dataset, along with 310 scales newly created or adapted from existing scales. These scales were examined in terms of domain, constructs, positive scales, adapted or created scales, scale validation, and operationalization of popular constructs.

Domains. As positive psychology research stems from various sub-disciplines of psychology, the measures cited were coded for the domain of origin, defined as the discipline of the journal within which a scale was originally published. The domains included social, cognitive, developmental, organizational, personality, counseling, clinical, school/educational, pediatric, and applied psychology.

Constructs. We examined the constructs measured in each scale to identify those that had attracted the most scholarly attention. In cases where the scale name was ambiguous as to the construct being measured, we:

1) reviewed the article(s) that cited the scale for further information,

2) cross-referenced the primary source of scale development to ascertain what the scale was designed to measure, and

3) examined other articles in which the scale was used to identify the specific construct being measured.

Positive scales. The first step was to determine whether a scale fit with the definition of positive psychology. Scales were determined to be aligned with positive psychology if they measured "valued subjective experiences" and states like wellbeing, satisfaction, hope, optimism, flow, and happiness; individual traits like the capacity for love, courage, perseverance, forgiveness, spirituality, and wisdom; or institutional features like responsibility, altruism, organizational citizenship, tolerance, and work ethic (Seligman \& Csikszentmihalyi, 2000, p. 5). In other words, scales were considered positive if they measured a construct that is life-giving, that encourages greater wellbeing, or that promotes flourishing (Seligman \& Csikszentmihalyi, 2000). To identify the most cited ${ }^{1}$ positive scales, we calculated the total number of times each scale was employed in a study. (Some articles have multiple studies.) In addition, information on scale construction and validity, and the structure of the scale was obtained through examination of the original scale development articles, and subsequent validations or updates, if any.

Citations outside of the dataset. A Google Scholar citation analysis was conducted in September 2018 to determine how often the most popular measurement articles from the dataset until 2014 were cited and whether they had gained traction outside of the dataset more recently. Google Scholar citations represent the number of times the scale's source article was cited, rather than the number of times the scale was used. In contrast, our citation analysis based on the dataset counts how many times a scale was actually utilized to measure a construct in an empirical study. Thus, the review from the dataset offers a conservative estimate of the popularity of a measurement (assessed through actual use), whereas the Google Scholar citation analysis offers a sense of the broader impact of the measurement article.

Adapted and newly developed scales. To assess the number of scales adapted, we coded information on the researchers who adapted the scale for use in their study and identified the aspects that were adapted. We relied on each article's methods to determine whether a scale was adapted or developed. A scale was considered to be newly developed if it was newly

\footnotetext{
${ }^{1}$ When a measure is referred to as "used" or "cited," we mean that the measure was utilized in the article as a measurement tool, rather than merely mentioned. We do not count it as a "citation" if an article that published the scale was referenced, but the scale was not used in the study.
} 
created or deviated considerably from the scale it was inspired by. For example, if the new scale was intended to measure a different construct than the original scale (e.g., compassion versus empathy), it was coded as a newly developed scale. Scales were considered to be adapted if the item wording was altered to fit a specific population or setting or if other minor changes were made. In each case, we recorded the source of the scale cited, items used from the other scale, and author(s).

Scale validation. To examine the extent to which scales are validated in well-developed programs of research, we recorded any validation studies or reliability analyses found in the dataset and noted the number of times the validation or reliability of a scale was a focus of the article. These instances were considered scale validations only if "validation" was explicitly mentioned by the authors and data on the reliability or validity of the scale were presented. While most articles that develop and introduce a new scale also undertake and report preliminary validation, we limited our definition of a scale validation to additional validation research conducted outside of the initial scale development. For example, a standalone study of a scale's validity and reliability conducted after the scale was developed would count as a scale validation article. Similarly, studies that use previously developed scales and report some psychometric information such as internal validity, but do not undertake scale validation to assess the scale itself, such as factor analysis, construct validation, etc. are not considered validation studies for the purpose of this review.

We also conducted a search for scale validations and reliability analyses undertaken outside of the positive psychology dataset. A sample of scales was selected from the dataset to compare the number of validation studies within the dataset with the number of validations outside of the dataset. We searched for validation studies on Google Scholar using the scale name and the search terms "validate" and/or "validation."

Multiple operationalizations. As an exploratory investigation and supplementary analysis, we reviewed the most popular constructs for the existence of multiple operationalizations, that is, the existence of more than one distinct definition of the same construct, which can result in different ways of measuring that construct. We noted any instances of significant differences in construct definition or operationalizations.

\section{Results}

The dataset of 972 empirical articles yielded 762 articles that used measurement scales in their methods, which became the basis for all further analyses. Findings revealed that a total of 1,279 measures were cited, and 310 measures were newly created or adapted from established scales. For a full list of the measures and citations archived in this dataset, please visit https://works.bepress.com/meg-warren/33/. Nearly 73\% $(\mathrm{n}=932)$ of established measures and $89 \%(\mathrm{n}=275)$ of newly created or adapted measures were cited only once in this dataset, only $14 \%(n=176)$ of established measures and $9 \%(n=27)$ of newly created or adapted measures were cited twice in this dataset, while $5 \%(n=58)$ and $1 \%(n=3)$ of the established and newly created or adapted measures were cited three times, respectively. The following sections summarize the key characteristics of the measurement literature.

\subsection{Domains}

The disciplinary domains that were the most generative in terms of positive psychology measurement were assessed by examining the journals in which the articles were published. The journals which published the top 25 most cited measures are presented in Table 1 below. The top-ranking Journal of Personality and Social Psychology was the most popular outlet, such 
that more positive psychology scale development articles were published here than in any other journal.

Table 1. Domains that publish positive psychology measures

\begin{tabular}{|c|c|c|}
\hline Domain & Count & Journals \\
\hline Social Psychology & 12 & $\begin{array}{l}\text { Journal of Personality and Social Psychology, Journal } \\
\text { of Personality, Journal of Personality Assessment, Self } \\
\text { and Identity, Social Psychology Quarterly }\end{array}$ \\
\hline Clinical Psychology & 4 & $\begin{array}{l}\text { Assessment, Journal of Clinical Psychology, Journal of } \\
\text { Mental Health, Journal of Traumatic Stress }\end{array}$ \\
\hline $\begin{array}{l}\text { Applied Psychology/ } \\
\text { Management }\end{array}$ & 2 & $\begin{array}{l}\text { Journal of Counseling Psychology, Personnel } \\
\text { Psychology }\end{array}$ \\
\hline Multidisciplinary & 2 & American Psychologist, Psychological Reports \\
\hline Social Sciences, General & 2 & Social Indicators Research \\
\hline Educational Psychology & 1 & School Psychology International \\
\hline Pediatric Psychology & 1 & Journal of Pediatric Psychology \\
\hline Positive Psychology & 1 & Journal of Happiness Studies \\
\hline
\end{tabular}

As another method to triangulate the disciplinary influences/domains that underlie the scales, the departmental affiliations of the first authors were examined. Out of the 25 most cited scales, 22 first authors were based in psychology departments (i.e., clinical, educational, health, and school psychology), two in sociology, and one in management. These affiliations map on to the journals in which the articles were published.

\subsection{Constructs}

Findings reveal that a wide range of constructs has been studied in research linked to positive psychology, including constructs that are inherently positive (such as wellbeing and happiness) as well as those with pathological undertones (such as depression and anxiety). Unsurprisingly, wellbeing is one of the most cited constructs, with 39 scales measuring some form of wellbeing, although pathology-focused scales were also used extensively in the dataset articles (see Table 2 below). For instance, 36 scales of depression were used in the dataset, which is equal to the number of happiness (including subjective wellbeing) scales used. The 10 most cited scales in the dataset measured constructs that were evenly split between pathologyfocused and positive psychological constructs. Furthermore, the frequent use of scales on constructs such as post-traumatic growth and coping suggests that the study of positive responses to adverse situations is also an important undertaking in positive psychology. It should be noted that in this review, we use the terminology used by the original developers to identify the construct measured. We do not impose a categorization if it was not intended by the original developers. This strategy, however, also implies that there is likely some gray area in these counts. In cases where a scale measured multiple constructs (e.g., happiness and depression), the scale was counted in both groups (e.g., as both a happiness scale and a depression scale). 
Table 2a. Most cited constructs in cited scales

\begin{tabular}{|c|c|c|c|}
\hline Construct & Sub-Construct (if any) & $\begin{array}{l}\text { Number of } \\
\text { Scales }\end{array}$ & Representative Scales \\
\hline \multirow[t]{4}{*}{ Wellbeing } & General Wellbeing & 39 & SPWB (Ryff, 1989) \\
\hline & $\begin{array}{l}\text { Happiness/Subjective Well- } \\
\text { Being }\end{array}$ & 36 & $\begin{array}{l}\text { AHI (Seligman, Steen, Park \& } \\
\text { Peterson, 2005) }\end{array}$ \\
\hline & Life Satisfaction & 13 & SWLS (Diener et al., 1985) \\
\hline & Total & 88 & -- \\
\hline \multirow[t]{4}{*}{ Emotions and Mood } & $\begin{array}{l}\text { General Emotions/All } \\
\text { Emotions }\end{array}$ & 31 & FEQ (Fordyce, 1988) \\
\hline & Mood & 12 & $\begin{array}{l}\text { POMS (McNair, Lorr, \& Doppleman, } \\
\text { 1971) }\end{array}$ \\
\hline & $\begin{array}{l}\text { Specifically Positive } \\
\text { Emotions }\end{array}$ & 5 & DPES (Shiota, Keltner, \& John 2006) \\
\hline & Total & 48 & -- \\
\hline \multirow[t]{3}{*}{ Personality } & Non-Big Five & 28 & $\begin{array}{l}\text { Eysenck I6 Junior Questionnaire } \\
\text { (Eysenck \& Eysenck, 1975) }\end{array}$ \\
\hline & Big Five & 15 & $\begin{array}{l}\text { BFI/BFI-44 (John, Donahue, \& Kentle, } \\
\text { 1991) }\end{array}$ \\
\hline & Total & 43 & -- \\
\hline \multicolumn{2}{|l|}{ Depression } & 36 & $\begin{array}{l}\text { CES-D (Locke \& Putnam, 1971; } \\
\text { Radloff, 1977) }\end{array}$ \\
\hline \multirow{3}{*}{$\begin{array}{l}\text { Self-Esteem and Self- } \\
\text { Efficacy }\end{array}$} & Self-Esteem & 17 & RSE (Rosenberg, 1965) \\
\hline & Self-Efficacy & 14 & $\begin{array}{l}\text { GSES (Sherer, Maddux, Merdandante, } \\
\text { Prentice-Dunn, Jacobs, \& Rogers 1982) }\end{array}$ \\
\hline & Total & 31 & -- \\
\hline \multirow[t]{3}{*}{$\begin{array}{l}\text { Spirituality, } \\
\text { Religiosity, \& Faith }\end{array}$} & Spirituality & 18 & $\begin{array}{l}\text { BMMRS (Fetzer Institute \& National } \\
\text { Institute on Aging Working Group, } \\
\text { 1999) }\end{array}$ \\
\hline & Religiosity \& Faith & 11 & RCI-10 (Worthington et al., 2003) \\
\hline & Total & 29 & -- \\
\hline \multicolumn{2}{|c|}{ Physical/General Health } & 28 & $\begin{array}{l}\text { SF-8 (Ware, Kosinksi, Dewey, \& } \\
\text { Gandek 2001) }\end{array}$ \\
\hline \multicolumn{2}{|l|}{ Anxiety } & 26 & DASS (Lovibond \& Lovibond, 1995) \\
\hline \multicolumn{2}{|c|}{ Stress (not including post-traumatic stress) } & 24 & $\begin{array}{l}\text { PSS (Cohen, Kamarck, \& Mermelstein } \\
\text { 1983) }\end{array}$ \\
\hline \multicolumn{2}{|l|}{ Affect } & 23 & PANAS (Watson et al., 1988) \\
\hline \multicolumn{2}{|c|}{ Post-Traumatic Stress/Post-Traumatic Growth } & 23 & PTGI (Tedeschi \& Calhoun, 1996) \\
\hline \multicolumn{2}{|l|}{ Meaning/Purpose } & 22 & MLQ (Steger et al., 2006) \\
\hline \multicolumn{2}{|l|}{ Strengths } & 22 & VIA-IS (Peterson et al., 2005) \\
\hline \multicolumn{2}{|l|}{ Relationships } & 21 & ECR (Brennan, Clark, \& Shaver, 1998) \\
\hline
\end{tabular}


Table $2 b$. Most cited constructs in cited scales

\begin{tabular}{lll}
\hline Construct & $\begin{array}{l}\text { Number of } \\
\text { Scales }\end{array}$ & Representative Scales \\
\hline Coping & 20 & B-COPE (Carver, 1997) \\
Social Support & 18 & ISEL (Cohen \& Hoberman, 1983) \\
Identity/Identification & 16 & DIDS (Luyckx et al., 2008) \\
Values & 14 & SVS (Schwartz, 1992) \\
Resilience & 13 & ERS (Block \& Kremen, 1996) \\
Work/Job satisfaction & 13 & JAWS (Van Katwyk, Fox, Spector, \& \\
& & Kelloway,2000) \\
Hope & 12 & ADHS (Snyder et al., 1991) \\
Optimism/Life Orientation & 12 & LOT-R (Scheier et al., 1994) \\
Flow & 10 & Flow Scale (Csikszentmihalyi, 1990) \\
Quality of Life & 10 & QOLI (Frisch, Cornell, Villanueva, \& \\
& & Retzlaff, 1992) \\
Mental Health & 10 & GHQ (Goldberg \& Hillier, 1979) \\
\hline
\end{tabular}

Another observation is that scales with a focus on the individual, such as individual wellbeing, depression, and health, were used frequently in the dataset articles, while scales measuring interpersonal processes and relational or collective constructs, such as relationship quality and social support, were used less often. Thus, the critique of the individualistic bent of positive psychology (Christopher \& Hickinbottom, 2008) seems to be supported.

\subsection{Positive scales}

A summary of the most cited positive scales in the dataset is shown in Table 3 below. As noted earlier, measures were identified as positive if they measured traits, states, experiences, or institutional features that were "positive," as defined by Seligman and Csikszentmihalyi (2000). Nearly half $(47 \%)$ of the measures cited in the dataset articles met this definition. Unsurprisingly, measures of happiness and wellbeing are the most cited positive measures, with three of the most popular scales measuring wellbeing or subjective happiness, and another scale measuring positive and/or negative affect. It is important to note that the second most popular positive measure also assesses negative events or emotions (i.e., PANAS).

\subsection{Citations outside of the dataset}

An analysis of articles from Google Scholar (see Table 3) was conducted to examine the extent to which most cited measures from the dataset were cited outside of the dataset. These results demonstrate that some of positive psychology's most measured constructs are also of interest to those who publish outside of positive psychology. For instance, Diener and colleagues' Satisfaction with Life Scale (1985) was the most cited scale in the database, with 210 citations, and also boasted an impressive 20,766 citations on Google Scholar; however, analysis also indicated that the popularity of the scales within positive psychology does not always mirror the popularity of these scales outside of positive psychology. For example, the Values in Action Inventory of Strengths (VIA-IS; Peterson \& Seligman, 2004; Peterson \& Park, 2009) matched Snyder and colleagues' (1991) Hope Scale in use within the positive psychology 
dataset, but the VIA was cited 7,186 times according to Google Scholar, versus the Hope Scale with 3,507 citations.

Table 3. Most cited positive measurement scales

\begin{tabular}{|c|c|c|c|c|c|}
\hline Measure & Development & $\begin{array}{l}\text { Dataset } \\
\text { Citations }\end{array}$ & $\begin{array}{l}\text { Google } \\
\text { Scholar } \\
\text { Citations }\end{array}$ & Construct & $\begin{array}{l}\text { Source of } \\
\text { Development }\end{array}$ \\
\hline $\begin{array}{l}\text { Satisfaction with Life } \\
\text { Scale }\left(\text { SWLS }{ }^{1}\right)\end{array}$ & $\begin{array}{l}\text { Diener, Emmons, } \\
\text { Larsen, \& Griffin, } \\
1985\end{array}$ & 210 & 20,766 & Wellbeing & $\begin{array}{l}\text { Journal of Personality } \\
\text { Assessment }\end{array}$ \\
\hline $\begin{array}{l}\text { Positive and } \\
\text { Negative Affect } \\
\text { Schedule (PANAS) }\end{array}$ & $\begin{array}{l}\text { Watson, Clark, \& } \\
\text { Tellegen, } 1988\end{array}$ & 150 & 30,091 & $\begin{array}{l}\text { Positive and } \\
\text { Negative Affect }\end{array}$ & $\begin{array}{l}\text { Journal of Personality } \\
\text { and Social Psychology }\end{array}$ \\
\hline $\begin{array}{l}\text { Life Orientation } \\
\text { Test-Revised (LOT- } \\
\text { R) }\end{array}$ & Scheier et al., 1994 & 69 & 5,775 & Optimism & $\begin{array}{l}\text { Journal of Personality } \\
\text { and Social Psychology }\end{array}$ \\
\hline $\begin{array}{l}\text { Rosenberg Self- } \\
\text { Esteem Scale (SES) }{ }^{1}\end{array}$ & Rosenberg, 1965 & 51 & 34,716 & Self-Esteem & (Book) \\
\hline $\begin{array}{l}\text { Psychological } \\
\text { Wellbeing Scales } \\
\text { (PWBS) }\end{array}$ & Ryff, 1989 & 50 & 10,525 & Well-Being & $\begin{array}{l}\text { Journal of Personality } \\
\text { and Social Psychology }\end{array}$ \\
\hline $\begin{array}{l}\text { Hope Scale/Adult } \\
\text { Dispositional Hope } \\
\text { Scale (ADHS) }{ }^{12}\end{array}$ & Snyder et al., 1991 & 46 & 3,507 & Hope & $\begin{array}{l}\text { Journal of Personality } \\
\text { and Social Psychology }\end{array}$ \\
\hline $\begin{array}{l}\text { Values in Action } \\
\text { Inventory of } \\
\text { Strengths (VIA-IS) }{ }^{12}\end{array}$ & $\begin{array}{l}\text { Peterson \& } \\
\text { Seligman, 2004; } \\
\text { Peterson \& Park, } \\
2009\end{array}$ & 45 & 7,186 & $\begin{array}{l}\text { Character } \\
\text { Strengths }\end{array}$ & N/A \\
\hline $\begin{array}{l}\text { Gratitude } \\
\text { Questionnaire-6 } \\
\text { (GQ-6) }\end{array}$ & $\begin{array}{l}\text { McCullough, } \\
\text { Emmons, \& } \\
\text { Tsang, } 2002\end{array}$ & 42 & 2,189 & $\begin{array}{l}\text { Gratitude, } \\
\text { Grateful } \\
\text { Disposition }\end{array}$ & $\begin{array}{l}\text { Journal of Personality } \\
\text { and Social Psychology }\end{array}$ \\
\hline $\begin{array}{l}\text { Subjective } \\
\text { Happiness Scale } \\
(\mathrm{SHS})^{1}\end{array}$ & $\begin{array}{l}\text { Lyubomirsky \& } \\
\text { Lepper, } 1999\end{array}$ & 39 & 2,643 & Happiness & $\begin{array}{l}\text { Social Indicators } \\
\text { Research }\end{array}$ \\
\hline $\begin{array}{l}\text { Meaning in Life } \\
\text { Questionnaire } \\
\text { (MLQ) }\end{array}$ & $\begin{array}{l}\text { Steger, Frazier, } \\
\text { Oishi, \& Kaler, } \\
2006\end{array}$ & 32 & 2,207 & Meaning & $\begin{array}{l}\text { Journal of Counseling } \\
\text { Psychology }\end{array}$ \\
\hline \multicolumn{6}{|c|}{$\begin{array}{l}{ }^{1} \text { Indicates that there are alternate versions and translations cited in the dataset that are not included in these counts. } \\
\text { 2Indicates that the scale has been validated in a separate study beyond its initial development. } \\
\text { Note: The Center for Epidemiological Studies Depression Scale (CES-D; Locke \& Putnam, 1971) was the third most } \\
\text { used scale (tied with the LOT-R, described below) with } 69 \text { citations, although this was the exception in the mostly- } \\
\text { positive list. }\end{array}$} \\
\hline
\end{tabular}


Figure 2. Citations per year for the most popular positive scales published before 1998

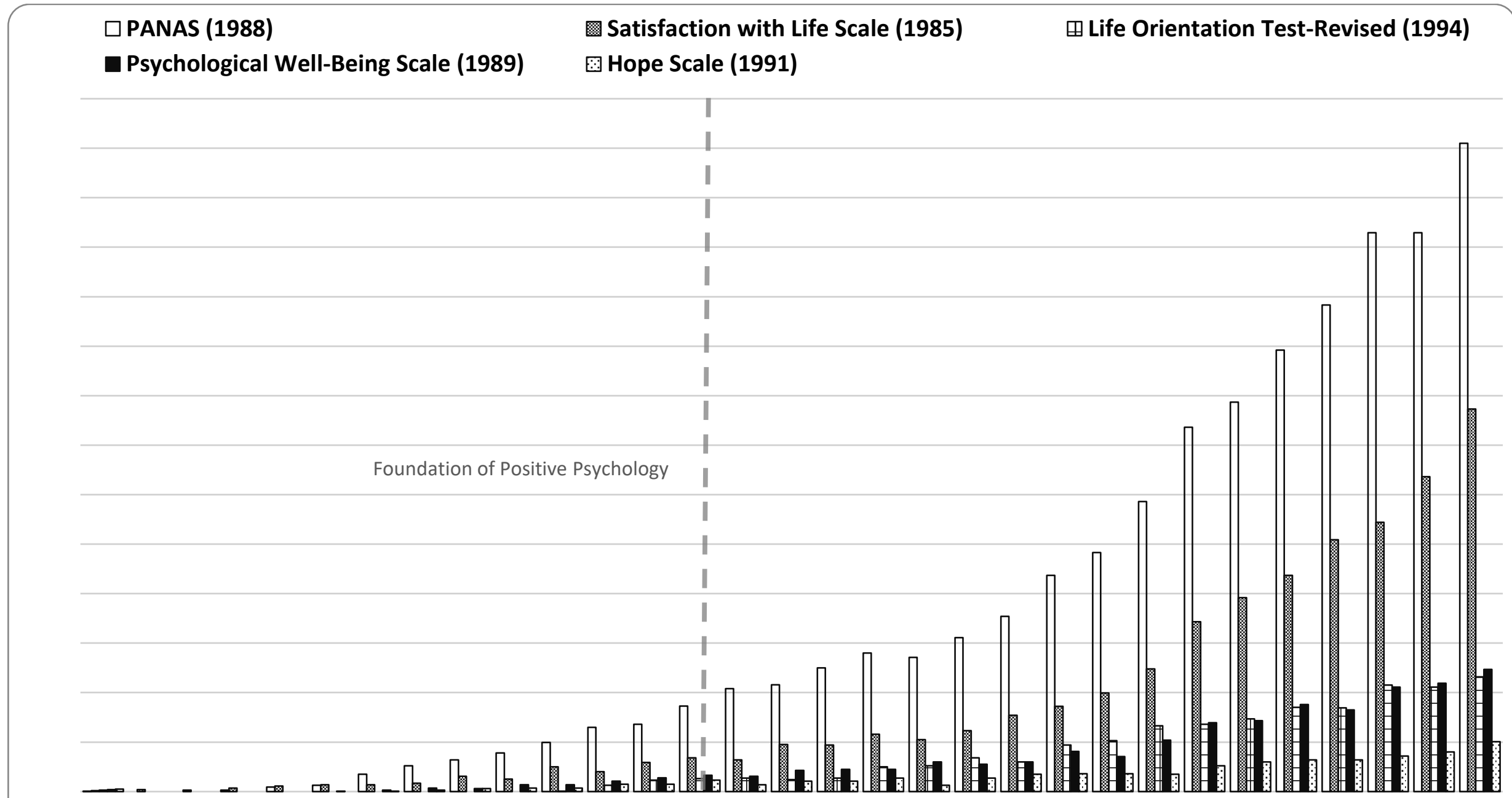

Note: This figure displays the number of citations per year since the scale's development for each of the five most popular scales in positive psychology created before its inception in 1998. 
Although these findings can provide an interesting look into topics that are popular in the general psychological literature but not within positive psychology and vice versa, what is useful to note is that four of the most prominent positive scales were published before positive psychology was formally established as a sub-discipline of psychology: the Satisfaction with Life Scale by Diener and colleagues was published in 1985, the Life Orientation Test-Revised by Scheier and colleagues was published in 1994, the Psychological Well-Being Scale by Ryff was published in 1989, and the Hope Scale by Snyder and colleagues was published in 1991. A comparison of the citations before and after 1998 (when the positive psychology movement began) shows a marked increase in citations per year starting in the early 2000s. While some of this may be attributed to maturation effects, the positive psychology movement may have played a role in the growth of popularity of the scales. See Figure 2 for a visualization of citations for these scales over time, pre- and post-formal establishment of positive psychology as a sub-field of psychology.

\subsection{Adapted and newly developed scales}

Examination of new scale creation and adaptation can provide insight into the growth of measurement in the field, areas that are lacking in validated measurement instruments, and scales frequently adapted to fit various populations or contexts. In all, 310 scales cited in the dataset were found to be adapted or developed in the articles. These were evenly split between adapted $(n=155)$ and newly developed $(n=155)$. In this set of scales, the majority $(n=275)$ were cited only once, with 27 scales receiving two citations, and only three scales receiving three citations. Many of the scales cited more than once were only cited multiple times on account of these scales being used by the original authors in subsequent studies.

Table 4. Most popular constructs in newly developed and adapted scales

\begin{tabular}{llll}
\hline Construct & Sub-Construct (if any) & Scales Developed & Scales Adapted \\
\hline Wellbeing & General Wellbeing & 9 & 2 \\
& Happiness/SWB/Joy & 6 & 3 \\
\cline { 2 - 4 } & Life Satisfaction & 3 & 2 \\
\cline { 2 - 4 } & Total & 18 & 7 \\
\hline Emotions and Mood & Emotions* & 10 & 4 \\
& Mood & 6 & 4 \\
\cline { 2 - 4 } & Total & 16 & 8 \\
\hline Affect & 3 & 5 \\
Goal Setting/Striving & 3 & 2 \\
Optimism/Life Orientation & 4 & 7 \\
Engagement & 1 & 7 \\
Hope & 2 & 4 \\
Meaning & 4 & 4 \\
Spirituality/Spiritual Development & 5 & 1 \\
Elevation & 3 & 2 \\
Trust & 0 & 5 \\
Strengths & 3 & 4 \\
\hline
\end{tabular}

"This category includes only general emotions measures, not measures of a specific emotion like happiness or anger. 


\subsection{Constructs studied}

The most popular constructs for new scale development and adaptation are depicted in Table 4 . As with the existing scales, we refer to the terminology used by the original developers to identify the construct measured. The analyses also revealed several new scale developments and a broad range of constructs measured, both indicative of the increasing maturity of the field and greater attention to context. Although wellbeing has received much attention within and outside positive psychology, and many established scales already exist, findings revealed nine new scales created to measure different types of wellbeing in specific contexts (e.g., wellbeing at work, student wellbeing). The development of new scales customized for particular contexts indicates a growing interest in going beyond basic measurement of subjective wellbeing and focusing on more nuanced application. In a similar vein, previously established measures of engagement were not among the most popular positive psychology scales, but these have spurred several new adaptations and creations focused on application in new contexts.

Table 5. Reliability and validity analysis within the dataset

\begin{tabular}{lll}
\hline Type & Subtype & Number of Studies* \\
\hline Reliability & Internal Consistency & 21 \\
& Test-retest Reliability & 5 \\
& Composite Reliability & 1 \\
\hline Validity & Construct & 11 \\
& Convergent & 8 \\
& Discriminant & 7 \\
& Predictive & 4 \\
& Incremental & 3 \\
& Criterion & 2 \\
& Concurrent & 2 \\
& Cross-cultural & 1 \\
& Treatment & 1 \\
\hline Factor Structure & Confirmatory Factor Analysis & 25 \\
& Exploratory Factor Analysis & 15 \\
& Structural Equation Modeling & 5 \\
& Invariance & 5 \\
& Categorical Factor Analysis & 1 \\
& Joint Modeling & 1 \\
& Meta-Analysis & 1 \\
& Principal Components Analysis & 1 \\
Temporal Stability & 1 \\
\hline
\end{tabular}

*The total number of articles describing reliability/validity analysis was 38 . 
Table 6. Explicit validation of a sample of scales from the most popular constructs

\begin{tabular}{|c|c|c|}
\hline Scale & Construct & $\begin{array}{l}\text { Number of } \\
\text { Validations* }\end{array}$ \\
\hline $\begin{array}{l}\text { Post-Traumatic Growth Inventory (PTGI; Tedeschi } \\
\text { \& Calhoun, 1996) }\end{array}$ & $\begin{array}{l}\text { Post-Traumatic } \\
\text { Growth }\end{array}$ & 13 \\
\hline $\begin{array}{l}\text { Profile of Mood States (POMS; McNair, Lorr, \& } \\
\text { Doppleman, 1971) }\end{array}$ & Mood & 12 \\
\hline $\begin{array}{l}\text { Personal Growth Initiative Scale (PGIS; Robitschek, } \\
\text { 1998) }\end{array}$ & Growth & $8(1)$ \\
\hline General Self-Efficacy Scale (GSES; Sherer et al, 1982) & Self-Efficacy & 7 \\
\hline $\begin{array}{l}\text { VIA Inventory of Strengths (Peterson \& Seligman, } \\
\text { 2004; Peterson \& Park, 2009) }\end{array}$ & Strengths & $7(3)$ \\
\hline Student Life Satisfaction Scale (SLSS; Huebner, 1991) & Life Satisfaction & 6 \\
\hline $\begin{array}{l}\text { Quality of Life Inventory (QOLI; Frisch, Cornell, } \\
\text { Villanueva, \& Retzlaff, 1992) }\end{array}$ & Quality of Life & $5(1)$ \\
\hline $\begin{array}{l}\text { Gratitude Questionnaire (GQ-6; McCullough, } \\
\text { Emmons, \& Tsang, 2002) }\end{array}$ & Gratitude & $3(3)$ \\
\hline Hope Scale (Snyder et al., 1991) & Hope & $3(2)$ \\
\hline $\begin{array}{l}\text { Gratitude, Resentment, and Appreciation Test, short } \\
\text { form (Grat-short form; Watkins, Woodward, Stone, } \\
\& \text { Kolts, 2003) }\end{array}$ & Gratitude & $2(1)$ \\
\hline $\begin{array}{l}\text { Purpose in Life Test (PIL; Crumbaugh \& Maholick, } \\
\text { 1964) }\end{array}$ & $\begin{array}{l}\text { Purpose / } \\
\text { Meaning }\end{array}$ & 2 \\
\hline $\begin{array}{l}\text { Steen Happiness Index (SHI; Seligman, Steen, Park, } \\
\text { \& Peterson 2005) }\end{array}$ & Happiness & 2 \\
\hline $\begin{array}{l}\text { Stress-Related Growth Scale (SRGS; Park, Cohen, \& } \\
\text { Murch, 1996) }\end{array}$ & $\begin{array}{l}\text { Post-Traumatic } \\
\text { Growth }\end{array}$ & 2 \\
\hline $\begin{array}{l}\text { Strengthspotting Scale (Linley, Garcea, Hill, Minhas, } \\
\text { Trenier, \& Willars, 2010) }\end{array}$ & Strengths & 2 \\
\hline B-COPE (Carver, 1997) & Coping & 1 \\
\hline $\begin{array}{l}\text { Dispositional Positive Emotion Scale (DPES; Shiota, } \\
\text { Keltner, \& John, 2006) }\end{array}$ & Positive Emotion & $1(1)$ \\
\hline $\begin{array}{l}\text { Orientation to Happiness Scale (Peterson, Park \& } \\
\text { Seligman, 2005) }\end{array}$ & Happiness & $1(1)$ \\
\hline $\begin{array}{l}\text { Positive Youth Development measure (Lerner et al., } \\
\text { 2005) }\end{array}$ & $\begin{array}{l}\text { Positive Youth } \\
\text { Development }\end{array}$ & $1(1)$ \\
\hline Social Well-Being Scale (SWBS; Keyes, 1998) & Wellbeing & 1 \\
\hline Schwartz Value Survey (SVS; Schwartz, 1992) & Values & 1 \\
\hline Strengths Use Scale (SUS; Govindji \& Linley, 2007) & Strengths & $1(1)$ \\
\hline
\end{tabular}

"Counted using Google Scholar.

Note: Numbers in parentheses indicate the number of times a scale was explicitly validated in later studies in the dataset.

\subsection{Scale validation and reliability analysis}

Some researchers have argued that a relative dearth of scale validation may indicate that the field is lacking cohesion, while the presence of many validation studies could signal that the field is more mature (Romano, 2001). We examined whether the scales had been the subject of 
further reliability analysis or explicitly validated by a study after the initial scale development, and, if so, how many times validation or reliability studies appeared in the dataset. We used the keywords "reliability" and/or "validity" to screen for articles that offer additional validation information and reviewed these articles in depth to determine whether any original reliability or validity analysis had been conducted. A total of 38 scales used in the dataset articles were also validated in later articles. Thirty-five (92\%) of these scales had one validation study each, the Hope Scale (Snyder et al., 1991) was validated twice, and the VIA-IS (Peterson, Park, \& Seligman, 2005) and the Gratitude Questionnaire (GQ-6, McCullough, Emmons, \& Tsang, 2002) were each validated in three separate studies.

We reviewed each of the 38 articles in which the authors conducted further reliability or validity analysis on these scales. The results are found in Table 5. Twenty-three used some kind of reliability analysis, 27 conducted analysis on the validity of the measure, and 34 tested the factor structure of the measure.

The results of our search for scale validations outside of the dataset showed that, as expected, slightly more scale validation and reliability studies were found outside of the dataset for topics with broad interest (e.g., Personal Growth Initiative Scale; Robitschek, 1998), while the validations in the dataset corresponded with those found in Google Scholar for explicitly positive topics (e.g., gratitude: McCullough et al., 2002; Orientation to Happiness Scale: Peterson et al., 2005; see Table 6 for more information).

\subsection{Multiple operationalizations}

The presence of multiple operationalizations (i.e., more than one definition of a concept, resulting in multiple ways to measure it) can lead to confusion in practice and may indicate a lack of cohesion in the field. Findings revealed two core positive psychology concepts that are caught in this quagmire-hope and wellbeing.

\subsubsection{Hope}

Seven different measurement systems of hope were identified in the positive psychological literature. Snyder's conceptualization of hope was the definition most often used or adapted (e.g., Sympson, 1999) to measure the presence of hope, although not exclusively. This definition divides hope into two components: agency, which refers to motivation and belief in one's ability to attain one's goals, and pathways, which concerns the planning of ways to meet these goals (Snyder et al., 1991). The Hope Index of Pacico and colleagues (2013) utilizes Staats' definition of hope (Staats \& Stassen, 1985), i.e., an interaction between one's wishes and expectations, including an affective component (wishing for positive future events), and a cognitive component (appraisal of the extent to which one these future positive events are likely to occur). The Hunter Opinions and Personal Expectations Scale (HOPES; Nunn \& Thompson, 1996) conceptualizes hope as a unidimensional construct that reaches through seven domains: mastery or control, meaning and purpose of life, perceived future interpersonal support, perceived future self-worth, planning (or investing in the future), motivation and sense drive, and reality appreciation. Further, the VIA also includes a subscale measuring hope, which is defined as "expecting the best in the future and working to achieve it" or "believing that a good future is something that can be brought about" (Park, Peterson, \& Seligman, 2004). See Table 7 below for definitions and scale items. 
Table 7. The many conceptualizations of hope

\begin{tabular}{|c|c|c|c|}
\hline $\begin{array}{l}\text { Scale } \\
\text { Construct }\end{array}$ & Scale & Definition & Representative Items \\
\hline $\begin{array}{l}\text { Dispositional } \\
\text { hope }\end{array}$ & $\begin{array}{l}\text { Adult Dispositional } \\
\text { Hope Scale (Snyder } \\
\text { et al., 1991) }\end{array}$ & $\begin{array}{l}\text { Defined as a two-component } \\
\text { cognitive set composed of agency } \\
\text { (goal-directed determination) and } \\
\text { pathways (planning of ways to meet } \\
\text { goals). }\end{array}$ & $\begin{array}{l}\text { Agency: 'I energetically pursue } \\
\text { my goals;' 'I've been pretty } \\
\text { successful in life.' Pathways: 'I } \\
\text { can think of many ways to get } \\
\text { out of a jam;' ‘There are lots of } \\
\text { ways around any problem.' }\end{array}$ \\
\hline $\begin{array}{l}\text { State } \\
\text { dispositional } \\
\text { hope }\end{array}$ & $\begin{array}{l}\text { State Hope Scale } \\
\text { (Snyder et al.,1996) }\end{array}$ & $\begin{array}{l}\text { Same as above, but more focused on } \\
\text { the present (closer to state instead of } \\
\text { trait). }\end{array}$ & $\begin{array}{l}\text { Agency: 'At the present time, I } \\
\text { am energetically pursuing my } \\
\text { goals.' Pathways: 'There are lots } \\
\text { of ways around any problem that } \\
\text { I am facing now.' }\end{array}$ \\
\hline Hope & $\begin{array}{l}\text { Domain Specific } \\
\text { Hope Scale-Revised } \\
\text { (Sympson, 1999) }\end{array}$ & $\begin{array}{l}\text { Same definition as Snyder in his } \\
\text { Adult Dispositional Hope Scale, but } \\
\text { limited to specific domains: social, } \\
\text { academic, family, romantic } \\
\text { relationships, occupation, and } \\
\text { leisure activities. }\end{array}$ & $\begin{array}{l}\text { Social: 'I actively pursue } \\
\text { friendships.' Academics: 'I } \\
\text { energetically pursue my school } \\
\text { work.' Romantic relationships: 'I } \\
\text { can usually get a date when I set } \\
\text { my mind to it.' }\end{array}$ \\
\hline $\begin{array}{l}\text { Goal-specific } \\
\text { hope }\end{array}$ & $\begin{array}{l}\text { Goal-Specific Hope } \\
\text { Scale (Feldman et al., } \\
\text { 2009) }\end{array}$ & $\begin{array}{l}\text { Feldman and colleagues use the } \\
\text { same conceptualization of hope as } \\
\text { Snyder's Adult Dispositional Hope } \\
\text { Scale, but limit the hope measured } \\
\text { to specific goals. }\end{array}$ & $\begin{array}{l}\text { Agency: 'I energetically pursue } \\
\text { this goal.' Pathways: 'I can think } \\
\text { of many ways to achieve this } \\
\text { goal.' }\end{array}$ \\
\hline $\begin{array}{l}\text { Cognitive } \\
\text { hope }\end{array}$ & $\begin{array}{l}\text { Hope Index, } \\
\text { Brazilian version } \\
\text { (Pacico et al., 2013) }\end{array}$ & $\begin{array}{l}\text { Staats (author of original Hope } \\
\text { Index) defined hope as an } \\
\text { interaction between an individual's } \\
\text { wishes and their expectations. Hope } \\
\text { consists of an affective and a } \\
\text { cognitive component; the affective } \\
\text { component involves wishing or } \\
\text { expecting for a future good or } \\
\text { pleasurable event, while the } \\
\text { cognitive component refers to the } \\
\text { expectations that this future event is } \\
\text { likely to occur. }\end{array}$ & $\begin{array}{l}\text { 'To be more competent;' ‘To have } \\
\text { good health;' ‘Other people to be } \\
\text { more helpful.' }\end{array}$ \\
\hline $\begin{array}{l}\text { Global } \\
\text { personal } \\
\text { hopefulness } \\
(\mathrm{GPH})\end{array}$ & $\begin{array}{l}\text { Hunter Opinions } \\
\text { and Personal } \\
\text { Expectations Scale } \\
\text { (Nunn \& } \\
\text { Thompson., 1996) }\end{array}$ & $\begin{array}{l}\text { Hope is a unidimensional construct } \\
\text { that consists of seven domains: } \\
\text { mastery or control, meaning and } \\
\text { purpose of life, perceived future } \\
\text { interpersonal support, perceived } \\
\text { future self-worth, planning } \\
\text { (investing in the future), motivation } \\
\text { and sense drive, reality } \\
\text { appreciation. }\end{array}$ & $\begin{array}{l}\text { 'I generally look forward to new } \\
\text { activities and phases in my life;' } \\
\text { 'I am the sort of person who } \\
\text { believes that life is full of } \\
\text { meaning;' 'I believe that I can } \\
\text { handle most of the difficulties } \\
\text { that I might have to face.' }\end{array}$ \\
\hline Hope & $\begin{array}{l}\text { VIA-IS (Peterson et } \\
\text { al., 2005) }\end{array}$ & $\begin{array}{l}\text { Hope as optimism, future- } \\
\text { mindedness, future-orientation; } \\
\text { defined as expecting the best in the } \\
\text { future and working to achieve it, } \\
\text { and believing that a good future is } \\
\text { something that can be brought } \\
\text { about. }\end{array}$ & $\begin{array}{l}\text { 'Despite challenges, I always } \\
\text { remain hopeful about the future.' }\end{array}$ \\
\hline
\end{tabular}


Table 8. Wellbeing: A construct with many operationalizations

\begin{tabular}{|c|c|c|c|}
\hline Scale Construct & Scales & Definitions & Representative Items \\
\hline $\begin{array}{l}\text { Mental } \\
\text { wellbeing/Positive } \\
\text { mental health }\end{array}$ & $\begin{array}{l}\text { Warwick- } \\
\text { Edinburgh Mental } \\
\text { Wellbeing Scale } \\
\text { (Tennant et al., } \\
\text { 2007) }\end{array}$ & $\begin{array}{l}\text { Positive mental health: 'foundation } \\
\text { for wellbeing and effective } \\
\text { functioning for both the individual } \\
\text { and the community... [state] which } \\
\text { allows individuals to realize their } \\
\text { abilities, cope with the normal } \\
\text { stresses of life, work productively } \\
\text { and fruitfully, and make a } \\
\text { contribution to their community.' }\end{array}$ & $\begin{array}{l}\text { 'I've been feeling optimistic } \\
\text { about the future;' 'I've been } \\
\text { feeling loved;' 'I've been } \\
\text { feeling cheerful;' all } \\
\text { answered in the score of } \\
\text { the last two weeks. }\end{array}$ \\
\hline $\begin{array}{l}\text { Psychological } \\
\text { wellbeing }\end{array}$ & $\begin{array}{l}\text { Psychological Well- } \\
\text { Being Scales/Scale of } \\
\text { Psychological Well- } \\
\text { Being (Ryff, 1989; } \\
\text { Ryff \& Keyes, 1995) }\end{array}$ & $\begin{array}{l}\text { Multifaceted definition that involves } \\
\text { positive psychological functioning, } \\
\text { six dimensions (self-acceptance, } \\
\text { positive relations with others, } \\
\text { autonomy, environmental mastery, } \\
\text { purpose in life, personal growth). }\end{array}$ & $\begin{array}{l}\text { Self-acceptance item: 'I like } \\
\text { most aspects of my } \\
\text { personality;' PRO item: } \\
\text { ‘People would describe me } \\
\text { as a giving person, willing } \\
\text { to share my time with } \\
\text { others;' Autonomy item: 'I } \\
\text { have confidence in my } \\
\text { opinions, even if they are } \\
\text { contrary to the general } \\
\text { consensus.' }\end{array}$ \\
\hline \multirow[t]{2}{*}{$\begin{array}{l}\text { Life satisfaction (or } \\
\text { global life } \\
\text { satisfaction) }\end{array}$} & $\begin{array}{l}\text { Satisfaction with } \\
\text { Life Scale (Diener et } \\
\text { al., 1985) }\end{array}$ & $\begin{array}{l}\text { 'A global assessment of a person's } \\
\text { quality of life according to his } \\
\text { chosen criteria' (p. 478). }\end{array}$ & $\begin{array}{l}\text { 'In most ways my life is } \\
\text { close to my ideal'; 'If I } \\
\text { could live my life over, I } \\
\text { would change almost } \\
\text { nothing.' }\end{array}$ \\
\hline & $\begin{array}{l}\text { Student's Life } \\
\text { Satisfaction Scale } \\
\text { (Huebner, 1991) }\end{array}$ & $\begin{array}{l}\text { Global life satisfaction: 'a general } \\
\text { evaluation of the quality of an } \\
\text { individual's life that is over and } \\
\text { above judgments of specific } \\
\text { domains' (p. 232). }\end{array}$ & $\begin{array}{l}\text { 'I like the way things are } \\
\text { going for me;' 'I feel good } \\
\text { about what's happening to } \\
\text { me;' 'My life is better than } \\
\text { most kids.' }\end{array}$ \\
\hline \multirow[t]{2}{*}{$\begin{array}{l}\text { Subjective } \\
\text { wellbeing/Happiness }\end{array}$} & $\begin{array}{l}\text { Subjective } \\
\text { Happiness Scale } \\
\text { (Lyubomirsky \& } \\
\text { Lepper, 1999) }\end{array}$ & $\begin{array}{l}\text { 'A global, subjective assessment of } \\
\text { whether one is a happy or unhappy } \\
\text { person' (p. 139). }\end{array}$ & $\begin{array}{l}\text { 'In general I consider } \\
\text { myself: not a very happy } \\
\text { person [1] ... a very happy } \\
\text { person [7]'; 'Compared } \\
\text { with most of my peers, I } \\
\text { consider myself: less happy } \\
\text { [1] ... more happy [7]' }\end{array}$ \\
\hline & $\begin{array}{l}\text { Affect Balance Scale } \\
\text { (Bradburn, 1969) }\end{array}$ & $\begin{array}{l}\text { Based on positive affect vs. negative } \\
\text { affect. }\end{array}$ & $\begin{array}{l}\text { 'During the past few } \\
\text { weeks, did you ever feel... } \\
\text { particularly excited or } \\
\text { interested in something?' } \\
\text { '...pleased about having } \\
\text { accomplished something?' } \\
\text { '...upset because someone } \\
\text { criticized you?' }\end{array}$ \\
\hline
\end{tabular}

\subsubsection{Wellbeing}

Wellbeing is perhaps the positive psychological construct with the most conceptualizations, and it has been defined and operationalized in numerous ways. In this analysis, five separate definitions of wellbeing and 39 scales were assessed. The common foundation of some of the prominent definitions is a positive perspective on mental health, in that mental health or 
wellbeing is viewed as a positive psychological state rather than the absence of mental illness. For example, the Warwick-Edinburgh Mental Well-Being Scale (Tennant et al., 2007) bases wellbeing on hedonic and eudaimonic aspects of mental health, rather than a lack of depression or disease. One exception is the Affect Balance Scale (Bradburn, 1969) that measures both positive and negative affect. Another common characteristic is the breadth of wellbeing; Ryff's (1989) and Ryff's and Keyes' (1995) scale consists of six dimensions of psychological functioning, while the SWLS (Diener et al., 1985), Student's Life Satisfaction Scale (Huebner, 1991), and the Subjective Happiness Scale (Lyubomirsky \& Lepper, 1999) measure wellbeing as a broad construct that supersedes satisfaction in any single life domain, and assess wellbeing on the individual's own criteria. As other researchers have noted, there is no universal definition of wellbeing, let alone a universal scale to measure wellbeing, as it is interpreted and studied variously in the context of relationships, life satisfaction, health, meaning, and spirituality (Lindert et al., 2015). Due to the multiple definitions and measurement styles, it is difficult to assess whether any measurement taps into the same facet as another. For representative items and definitions, please see Table 8 .

\section{Discussion}

The current review offers an overview of the measurement scales used in positive psychology. This review suggests that, as a budding area of scholarship, positive psychology has made promising strides. The most fundamental positive constructs and the scales used to measure them seem to be well-established, both within and outside of the dataset. There is also evidence of high generativity in terms of the recent development of a range of constructs and measures, and prolific growth in application (e.g., via adaptations of scales in new contexts).

Our results show that positive psychology research is conducted with a wide range of constructs beyond wellbeing and positive traits, and while it most often engages positive phenomena, it is not averse to considering suffering and adversity. The most frequently measured and studied topics in positive psychology are not the stereotypical happiness and positivity, but topics such as meaning, purpose, character strengths, values, positive relationships, social support, gratitude, spirituality, self-esteem, and self-efficacy.

Finally, our findings suggest that there is some attention afforded to negative phenomena. Five of the 10 most frequently measured constructs are related to depression, anxiety, and stress. The popularity of negative phenomena was surprising, although these measures may have been used for a variety of reasons (e.g., validation studies, evaluating the effectiveness of a positive psychology intervention). Many studies examine both positive as well as negative phenomena in the same study (e.g., reducing depression and increasing wellbeing). Further, some of the most popular positive measures focus on positive responses to adverse situations, such as coping, resilience, and post-traumatic growth. Thus, findings indicate that a portion of the literature associated with positive psychology is paying some attention to negative phenomena.

\section{Limitations and future directions}

While this review makes a unique contribution in examining measurement scales associated with positive psychology, it is important to view the findings in light of its limitations. Limiting the literature search to those that included the term "positive psychology" excludes articles that engage positive phenomena but did not make explicit mention of the term. As such, this is a restricted sample of the literature associated with positive psychology. Another limitation is that restriction to English-language articles underestimates contributions from 
non-English speaking countries and is therefore complicit with publication bias for Western phenomena. Finally, the dataset reviews articles published from 1998 to 2014, leaving a significant gap between the last year covered by the dataset and the current year. However, as we noted earlier, there is typically a several-year delay between the time of publication and the time when measures are actually used in the literature. Thus, the current review focuses on those that have existed for several years, allowing the scales to establish some degree of merit.

The findings indicate that there are some concerns related to multiple operationalization of key constructs, which we believe is a symptom of a larger issue. We expected to find some degree of multiple operationalization in the positive psychological literature, due to the presence of several sub-disciplinary influences (e.g., social, organizational psychology), and the complexity involved in defining and measuring some constructs. Happiness, for instance, is difficult to define, and scholars have differing perspectives on how to most accurately measure it (Waterman, 2008). One reason for this occurrence might be that a construct is of interest in multiple fields, each of which has its own epistemological biases, and there is inadequate discourse across disciplines. Another possible cause of multiple operationalization is researchers within the same field carving out their own theoretical niches. Regardless, while this is not necessarily a problem within a particular field, multiple operationalizations can pose difficulties in the interdisciplinary scholarship often necessary to solve multi-faceted, largescale social issues. This problem also poses the question: are all of the various definitions truly capturing the same construct? It would be fruitful for scholars to engage in greater crosspollination and exchange of knowledge across sub-disciplinary boundaries on similar constructs to reduce redundancy where possible.

Further, while there is a surge of new scale development, at this time, a large proportion of scales ( $89 \%$ of all scales cited) are cited only once or twice and validated even less. In addition to a need for more validation undertakings, this also suggests inadequate discourse. Greater integration and dialogue can facilitate researchers' use of existing scales rather than the creation of new ones for each study. Therefore, we recommend more organized interdisciplinary investigations around common interests and more dialogue across disciplines, and we call for more funding opportunities and publication outlets that can facilitate interdisciplinary discourse.

\section{Conclusion}

The field of positive psychology aims to promote a science of thriving and improve the quality of human life, among other aspirations (Seligman \& Csikszentmihalyi, 2000). As an organized area of inquiry, positive psychology has gained widespread interest and momentum across disciplines. This article attempts to generate greater discourse, bringing to light the many measurement scales that have been published and used in research. The recent proliferation of scales may be in part due to the current lack of discourse in positive psychology, as many scholars are as yet unaware of the existing scales that have already been developed (in addition to pet theories that scholars hold). Of course, this may also be a sign of healthy development in the field, as researchers push the boundaries of positive constructs and approach the constructs from varied perspectives. Regardless, as a rapidly growing field, the many measurements can be unwieldy and confusing, and this review helps map the scales and highlight existing contributions.

This prolific growth has brought renewed vigour and attention to the study of positive phenomena, as well as a range of perspectives, methodologies, and procedures for the study and measurement of positive constructs. This review offers new insight into the characteristics 
of positive psychological research, its scope, and major contributions in measurement. We conclude with a call for more discussion and exchange across disciplinary boundaries as the next step in realizing the field's full potential for growth. Deep integration and research across contexts emerging from interdisciplinary collaborative efforts are vital to the growth of a robust science of human flourishing.

\section{Authors}

Courtney E. Ackerman

Claremont Graduate University

courtney.e.ackerman@gmail.com

Meg A. Warren

Western Washington University

Stewart I. Donaldson

Claremont Graduate University

\section{Publishing Timeline}

Received 8 May 2018

Accepted 8 October 2018

Published 9 December 2018

\section{References}

Anderson, E. C. (2012). Review of smile or die: How positive thinking fooled America \& the world. Health: An Interdisciplinary Journal for the Social Study of Health, Illness and Medicine, 16(1), 109111. https://doi.org/10.1177/1363459311407798

Bradburn, N. M. (1969). The structure of psychological well-being. Oxford, England: Aldine.

Cabanas, E., \& Huertas, J. A. (2014). Positive psychology and self-help popular psychology: A historical, psychological and cultural romance. Anales De Psicología, 30(3), 852-864. https://doi.org/10.6018/analesps.30.3.169241

Chang, E. C., Downey, C. A., Hirsch, J. K., \& Lin, N. J. (2016). Positive psychology in racial and ethnic groups: Theory, research, and practice. Washington, DC: American Psychological Association. https://doi.org/10.1037/14799-000

Christopher, J. C., \& Hickinbottom, S. (2008). Positive psychology, ethnocentrism, and the disguised ideology of individualism. Theory \& Psychology, 18(5), 563-589. https://doi.org/10.1177/0959354308093396

Ciocanel, O., Power, K., Eriksen, A., \& Gillings, K. (2017). Effectiveness of positive youth development interventions: A meta-analysis of randomized controlled trials. Journal of Youth and Adolescence, 46(3), 483-504. https://doi.org/10.1007/s10964-016-0555-6

Cooke, P. J., Melchert, T. P., Connor, K. (2016). Measuring well-being: A review of instruments. The Counseling Psychologist, 44(5), 730-757. https://doi.org/10.1177/0011000016633507

Diener, E. (2013). The remarkable changes in the science of subjective well-being. Perspectives on Psychological Science, 8(6), 663-666. https://doi.org/10.1177/1745691613507583

Diener, E., Emmons, R. A., Larsen, R. J., \& Griffin, S. (1985). The Satisfaction with Life Scale. Journal of Personality Assessment 49(1), 71-75. https://doi.org/10.1207/s15327752jpa4901 13

Donaldson, S. I., Csikszentmihalyi, M., \& Nakamura, J. (2011). Applied positive psychology: Improving everyday life, health, schools, work, and society. New York, NY: Routledge / Taylor \& Francis.

Donaldson, S. I., Dollwet, M., \& Rao, M. A. (2015). Happiness, excellence, and optimal human functioning revisited: Examining the peer-reviewed literature linked to positive psychology. The Journal of Positive Psychology, 10(3), 185-195. https://doi.org/10.1080/17439760.2014.943801 
Feldman, D. B., Rand, K. L., \& Kahle-Wrobleski, K. (2009). Hope and goal attainment: Testing a basic prediction of hope theory. Journal of Social and Clinical Psychology, 28(4), 479-497. https://doi.org/10.1521/jscp.2009.28.4.479

Gagné, M., \& Deci, E. L. (2014). The history of self-determination theory in psychology and management. In M. Gagné (Ed.), The Oxford handbook of work engagement, motivation, and self-determination theory (pp. 1-9). New York, NY: Oxford University Press. https://doi.org/10.1093/oxfordhb/9780199794911.013.006

Huebner, E. S. (1991). Initial development of the Student's Life Satisfaction Scale. School Psychology International, 12(3), 231-240. https://doi.org/10.1177/0143034391123010

Joseph, S., \& Linley, P. A. (2008). Psychological assessment of growth following adversity: A review. In S. Joseph \& P. A. Linley (Eds.), Trauma, recovery, and growth: Positive psychological perspectives on posttraumatic stress (pp. 21-36). Hoboken, NJ: John Wiley \& Sons. https://doi.org/10.1002/9781118269718

Lindert, J., Bain, P. A., Kubzansky, L. D., \& Stein, C. (2015). Well-being measurement and the WHO health policy Health 2010: Systematic review of measurement scales. European Journal of Public Health 25(4), 731-740. https://doi.org/10.1093/eurpub/cku193

Linton, M., Dieppe, P., \& Medina-Lara, A. (2016). Review of 99 self-report measures for assessing wellbeing in adults: Exploring dimensions of well-being and developments over time. BMJ Open, 6, 1-16. https://doi.org/10.1136/bmjopen-2015-010641

Lyubomirsky, S., \& Lepper, H. S. (1999). A measure of subjective happiness: Preliminary reliability and construct validation. Social Indicators Research, 46(2), 137-155. https://doi.org/10.1023/A:1006824100041

McCullough, M. E., Emmons, R. A., \& Tsang, J. (2002). The grateful disposition: A conceptual and empirical topography. Journal of Personality and Social Psychology, 82(1), 112-127. https://doi.org/10.1037/0022-3514.82.1.112

Moher, D., Liberati, A., Tetzlaff, J., \& Altman, D. G. (2009). Preferred reporting items for systematic reviews and meta-analyses: The PRISMA statement. PLOS Medicine, 6(7), 1-6. https://doi.org/10.1371/journal.pmed.1000097

Nunn, K. P., \& Thompson, S. L. (1996). The pervasive refusal syndrome: Learned helplessness and hopelessness. Clinical Child Psychology and Psychiatry, 1(1), 121-132. https://doi.org/10.1177/1359104596011011

Pacico, J. C., Zanon, C., Bastianello, M. R., Reppold, C. T., \& Hutz, C. S. (2013). Adaptation and validation of the Brazilian version of the Hope Index. International Journal of Testing, 13(3), 193-200. https://doi.org/10.1080/15305058.2012.664833

Park, N., Peterson, C., \& Seligman, M. E. P. (2004). Strengths of character and well-being. Journal of Social and Clinical Psychology, 23(5) 603-619. https://doi.org/10.1521/jscp.23.5.603.50748

Peterson, C., Park, N., \& Seligman, M. E. P. (2005). Orientations to happiness and life satisfaction: The full life vs. the empty life. Journal of Happiness Studies, 6(1), 25-41. https://doi.org/10.1007/s10902-004-1278z

Peterson, C., \& Seligman, M. E. P. (2004). Character strengths and virtues: A handbook and classification. New York, NY: Oxford University Press and Washington, DC: American Psychological Association.

Proctor, C., Linley, P. A., \& Maltby, J. (2009). Youth life satisfaction measures: A review. The Journal of Positive Psychology, 4(2), 128-144. https://doi.org/10.1080/17439760802650816

Rao, M. A., \& Donaldson, S. I. (2015). Expanding opportunities for diversity in positive psychology: An examination of gender, race, and ethnicity. Canadian Psychology / Psychologie Canadienne, 56(3), 271282. https://doi.org/10.1037/cap0000036

Rao, M. A., Donaldson, S. I., \& Doiron, K. M. (2015). Positive psychology research in the Middle East and North Africa. Middle East Journal of Positive Psychology, 1(1), 60-76.

Romano, N. C. (2001). Customer relations management research: An assessment of sub field development and maturity. Proceedings from HICSS-34: $34^{\text {th }}$ Hawaii International Conference on System Sciences. Washington, DC: IEEE Computer Society. https://doi.org/10.1109/HICSS.2001.927052

Rosenberg, M. (1965). Society and the adolescent self-image. Princeton, NJ: Princeton University Press. 
Ruark, J. (2009). An intellectual movement for the masses 10 years after its founding, positive psychology struggles with its own success. Chronicle of Higher Education, 55(43), 4.

Ryff, C. D. (1989). Happiness is everything, or is it? Explorations on the meaning of psychological wellbeing. Journal of Personality and Social Psychology, 57(6), 1069-1081. https://doi.org/10.1037/0022$\underline{3514.57 .6 .1069}$

Ryff, C. D., \& Keyes, C. L. M. (1995). The structure of psychological well-being revisited. Journal of Personality and Social Psychology, 69, 719-727. https://doi.org/10.1037/0022-3514.69.4.719

Scheier, M. F., Carver, C. S., \& Bridges, M. W. (1994). Distinguishing optimism from neuroticism (and trait anxiety, self-mastery, and self-esteem): A reevaluation of the Life Orientation Test. Journal of Personality and Social Psychology 67(6), 1063-1078. https://doi.org/10.1037/0022-3514.67.6.1063

Seligman, M. E. P., \& Csikszentmihalyi, M. (2000). Positive psychology: An introduction. American Psychologist, 55(1), 5-14. https://doi.org/10.1037/0003-066X.55.1.5

Singh, K., Junnarkar, M., \& Kaur, J. (2016). Measures of positive psychology: Development and validation. New Delhi, India: Springer. https://doi.org/10.1007/978-81-322-3631-3

Smock, S. A. (2012). A review of solution-focused, standardized outcome measures and other strengthsoriented outcome measures. In C. Franklin, T. S. Trepper, E. E. McCollum, W. J. Gingerich (Eds.), Solution-focused brief therapy: A handbook of evidence-based practice (pp. 55-72). New York, NY: Oxford University Press.

Snyder, C. R., Harris, C., Anderson, J. R., Holleran, S. A., Irving, L. M., Sigmon, S. T., . . Harney, P. (1991). The will and the ways: Development and validation of an individual-differences measure of hope. Journal of Personality and Social Psychology, 60(4), 570-585. https://doi.org/10.1037/0022$\underline{3514.60 .4 .570}$

Snyder, C. R., Sympson, S. C., Ybasco, F. C., Borders, T. F., Babyak, M. A., \& Higgins, R. L. (1996). Development and validation of the State Hope Scale. Journal of Personality and Social Psychology, 70(2), 321-335. https://doi.org/10.1037/0022-3514.70.2.321

Staats, S. R., \& Stassen, M. A. (1985). Hope: An affective cognition. Social Indicators Research, 17(3), 235-242. https://doi.org/10.1007/BF00319312

Steger, M. F., Frazier, P., Oishi, S., \& Kaler, M. (2006). The meaning in life questionnaire: Assessing the presence of and search for meaning in life. Journal of Counseling Psychology, 53(1), 80-93. https://doi.org/10.1037/0022-0167.53.1.80

Stoner, C. R., Orrell, M., \& Spector, A. (2015). Review of positive psychology outcome measures for chronic illness, traumatic brain injury and older adults: Adaptability in dementia? Dementia and Geriatric Cognitive Disorders, 40(5-6), 340-357. https://doi.org/10.1159/000439044

Sympson, S. (1999). Validation of the Domain Specific Hope Scale: Exploring hope in life domain. Unpublished doctoral dissertation. University of Kansas, Lawrence, KS.

Tennant, R., Hiller, L., Fishwick, R., Platt, S., Joseph, S., Weich, S., . . Stewart-Brown, S. (2007). The Warwick-Edinburgh Mental Well-being Scale (WEMWBS): Development and UK validation. Health and Quality of Life Outcomes, 5, 63-75. https://doi.org/10.1186/1477-7525-5-63

Tsang, K. L. V., Wong, P. Y. H., \& Lo, S. K. (2012). Assessing psychosocial well-being of adolescents: A systematic review of measuring instruments. Child: Care, Health and Development, 38(5), 629-646. https://doi.org/10.1111/j.1365-2214.2011.01355.x

Tugade, M. M., Shiota, M. N., \& Kirby, L. D. (2014). Handbook of positive emotions. New York, NY: Guilford Press.

Waterman, A. S. (2008). Reconsidering happiness: A eudaimonist's perspective. The Journal of Positive Psychology, 3(4), 234-252. https://doi.org/10.1080/17439760802303002

Watson, D., Clark, L. A., Tellegen, A. (1988). Development and validation of brief measures of positive and negative affect: The PANAS scales. Journal of Personality and Social Psychology 54(6), 1063-1070. https://doi.org/10.1037/0022-3514.54.6.1063

Woodstock, L. (2005). Vying constructions of reality: Religion, science, and 'positive thinking' in self-help literature. Journal of Media and Religion, 4(3), 155-178. https://doi.org/10.1207/s15328415jmr0403 3 